\title{
Хірургічне лікування нирковоклітинного раку з внутрішньовенозним розповсюдженням та імплантаціею тромбу в стінку нижньої порожнистої вени
}

\author{
V. I. RUSYN, V. V. KORSAK, S. O. BOIKO, YA. M. POPOVYCH \\ SHEl "Uzhhorod National University"
}

\section{SURGICAL TREATMENT OF RENAL CELL CARCINOMA WITH INTERNALLY VENOUS DISSEMINATION AND IMPLANTATION OF THROMBUS IN INTRA VENA CAVA INFERIOR TISSUE}

\begin{abstract}
У роботі представлено результати хірургічного лікування нирковоклітинного раку з внутрішньовенозним розповсюдженням та імплантацією тромбу в стінку нижньої порожнистої вени. У 3 випадках виконано протезування нижньої порожнистої вени протезами Gore Tex чи ПТФЕ (2 - вище ниркових вен, 1 - нижче ниркових вен). Гістологічно підтверджена інвазія пухлинного тромбу при нирковоклітинному раку в стінку нижньої порожнистої вени є показанням до резекції стінки чи ділянки нижньої порожнистої вени, яка відновлюється за допомогою протезування.

This work presents the results of surgical treatment of renal cell carcinoma with internally venous dissemination and implantation of thrombus in intra vena cava inferior tissue. Prosthesis was performed in 3 cases a of vena cava inferior by Gore Tex or PTFE prothesis ( 2 - above the renal veins, 1 - below the renal veins). Histologically confirmed an invasion of tumor thrombus by renal cell carcinoma intra vena cava inferior tissue is an evidence to resection of tissue or an area of vena cava inferior which repairs via prosthesis.
\end{abstract}

Постановка проблеми і аналіз останніх досліджень та публікацій. Тромбоз у системі нижньої порожнистої вени (НПВ) - найбільш поширене захворювання, яке ускладнює перебіг післяопераційного періоду, вагітності та пологів, травм, онкологічних і різноманітних хронічних захворювань. Частота тромбозів у системі НПВ у розвинутих країнах складає 1-4 на 1000 населення [6, 7, 9]. На частку тромбозів у системі НПВ припадає більш ніж 95 \% усіх венозних тромбозів, з яких 10-25 \% ускладнюються тромбоемболією легеневої артерії (ТЕЛА) [10].

Тромбози глибоких вен системи НПВ часто виникають при онкологічній патології, зокрема раку нирки. За даними Національного канцер-реєстру, в Україні захворюваність на нирковоклітинний рак (НКР) у 2011 році становила 11,5 на 100 тис. населення [5]. Однією 3 клінічних характеристик місцевопоширеного НКР $є$ його схильність до імплантаційної інвазії тромбів у систему нижньої порожнистої вени (НПВ), що спостерігається у 4-14 \% випадків [1, 8].

Сучасний рівень судинної хірургії та підхід до радикального хірургічного лікування НКР з внутрішньовенозним розповсюдженням та імплантацією тромбу в стінку НПВ вимагає ширшого застосування складних комбінованих операцій 3 наступним відновленням кровотоку по магістральних судинах шляхом їх протезування. Тому об’єднання зусиль онкологів, урологів і судинних хірургів $є$ актуальним у вирішенні питання радикального хірургічного лікування даного контингенту хворих.

“Золотим стандартом” хірургічного лікування НКР залишається радикальна нефректомія, яка розширюється і доповнюється операційним втручанням на НПВ у випадках, ускладнених імплантаційним венозним тромбом. У більшості таких ситуацій операція закінчується розтином стінки вени з наступним видаленням тромбу з просвіту судини без виконання резекції чи пластики НПВ [1-3]. Одним із найбільш складних завдань $є$ забезпечення радикальності нефректомії і тромбектомії у випадку проростання пухлинного тромбу в стінку НПВ. Адже в такій ситуації виникає необхідність виконання резекції НПВ із

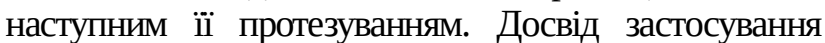
протезування НПВ під час хірургічного лікування місцевопоширеного НКР є невеликим. Так, М. И. Давыдов и соавт. та А. М. Гранов и соавт. повідомляють про власний досвід протезування НПВ $з$ приводу 
хірургічного лікування місцевопоширеного НКР у 3 пацієнтів [1, 2]. Обмежена кількість публікацій з приводу протезування НПВ під час хірургічного лікування місцевопоширеного НКР вимагає подальших розробок у даному напрямку з метою поліпшення результатів надання допомоги хворим з НКР за рахунок ширшого впровадження розширених операційних втручань із використанням різних видів ангіохірургії, в т. ч. і протезування НПВ. На сучасному етапі поставлене завдання можна виконати тільки завдяки злагодженим діям мультидисциплінарної команди хірургів.

Мета роботи: покращити результати хірургічного лікування нирковоклітинного раку з внутрішньовенозним розповсюдженням та імплантацією тромбу в стінку нижньої порожнистої вени.

Матеріали і методи. У дослідження включено 58 хворих на НКР, ускладнений внутрішньовенозним розповсюдженням та імплантацією тромбу в стінку НПВ. Вік пацієнтів перебував у межах від 30 до 78 років, середній вік - $(57 \pm 3,2)$ року. Всі хворі були прооперовані у хірургічній клініці Закарпатської обласної клінічної лікарні ім. А. Новака протягом 2009-2014 років.

Діагностичний алгоритм складався із загальноприйнятих в онкоурологічній практиці клінічних, лабораторних, променевих та гістологічних методів згідно 3 рекомендаціями Європейської асоціації урологів. В обов'язковому порядку виконували ультразвукове обстеження органів сечовидільної системи із доплерографією ниркових судин та нижньої порожнистої вени, мультиспіральну комп'ютерну чи магнітно-резонансну томографію з внутрішньовенним контрастним підсиленням, а при необхідності - ілеокаваграфію.

При виявленні пухлинного тромбу при нирковоклітинному раку рівень поширення тромботичної оклюзії в НПВ оцінювали відповідно до класифікації клініки Меуо (рис. 1), яка включає у себе 5 рівнів поширення пухлинного тромбу [8]:

- рівень 0 - тромб обмежений нирковою веною;

- рівень I- тромб до 2-х см входить у просвіт НПВ;

- рівень II - тромб поширюється до рівня печінкових вен;

- рівень III - тромб на рівні або вище печінкових вен, але до діафрагми;

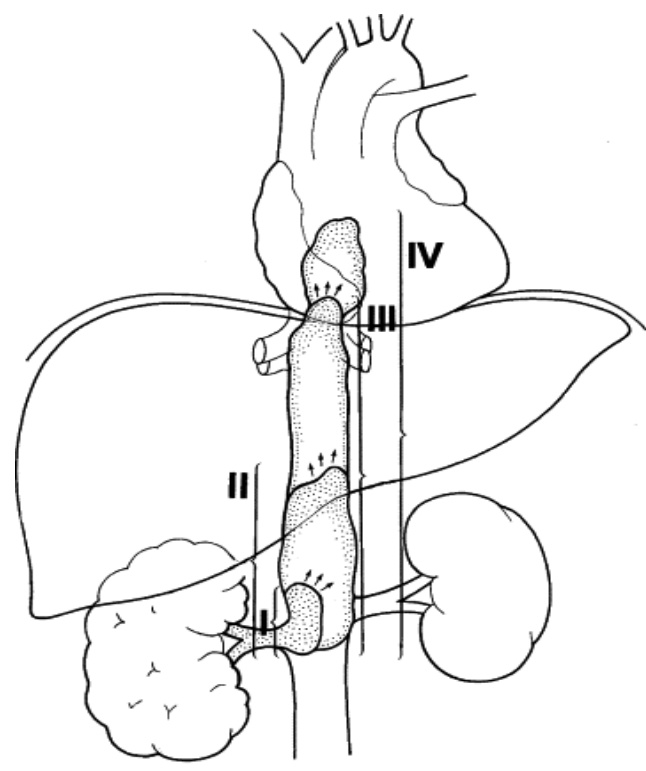

Рис. 1. Рівні поширення пухлинного тромбу в НПВ (клініка Меуо).

- рівень IV - тромб поширюється вище діафрагми.

Хворих з “нульовим” рівнем поширення пухлинного тромбу в дослідження не включали. У подальше дослідження включено 58 випадків з I-IV рівнями поширення пухлинного тромбу в НПВ (табл. 1).

Клініко-анатомічне стадіювання НКР проводили відповідно до класифікації ТNM Міжнародного протиракового союзу (UICC) 2002 року. У всіх випадках верифіковано світлоклітинний варіант НКР в ураженій пухлиною нирці та імплантаційному тромбі НПВ.

Усі пацієнти були прооперовані з лапаротомного доступу в одній із трьох модифікацій: трансабдомінальний двобічний підребровий доступ у модифікації за типом “Chevron” чи “Mercedes”. Під час операції використовували загальнохірургічні та судинні інструменти. Методи допоміжного і штучного кровообігу, що включають кардіопульмонарне шунтування, зупинку циркуляції і системну гіпотерміюневикористовували. Привидаленні пухлинних тромбів III і IV рівнів поширення у НПВ обов'язковим моментом було застосування мобілізації печінки з наступною ротацією правої частки печінки за методикою “piggyback” у ліве підребер”я. При видаленні ураженої пухлиною лівої нирки виконували мобілізацію “en block” у лівих відділах черевної порожнини.

Таблиця 1. Рівень поширення пухлинного тромбу в нижній порожнистій вені відповідно до класифікації клініки Меуо

\begin{tabular}{||l|c|c|c|c||}
\hline \multirow{2}{*}{ Рівень поширення тромбу } & \multicolumn{2}{|c|}{ Права нирка $(\mathrm{n}=69)$} & \multicolumn{2}{c||}{ Ліва нирка (n=31) } \\
\cline { 2 - 5 } & абс. & відн., \% & абс. & відн., \% \\
\hline 0 рівень & 33 & 47,8 & 9 & 29 \\
\hline I рівень & 6 & 8,7 & 14 & 45,2 \\
\hline II рівень & 14 & 20,3 & 6 & 19,4 \\
\hline III рівень & 13 & 18,8 & 1 & 3,2 \\
\hline IV рівень & 3 & 4,3 & 1 & 3,2 \\
\hline \hline
\end{tabular}


Неповна апаратна плікація НПВ за розробленою нами методикою [4] застосована у 33 випадках.

Протезування НПВ виконано протезами Gore Tex чи ПТФЕ у 3 хворих на рак правої нирки. У 2 випадках було застосовано супраренальне протезування, при якому ділянка впадання лівої ниркової вени в НПВ була відсічена й імплантована в протез. В одного пацієнта виконано інфраренальне протезування НПВ.

Результати досліджень та ї обговорення. “Золотим стандартом” виявлення тромботичної оклюзії НПВ залишається ультразвукове дослідження. При виявленні тромботичної оклюзії НПВ виділяють такі різновиди емболонебезпечного венозного тромбозу:

- сегментарний (фрагментарний) флотуючий тромб у венозній магістралі, який втратив точку фіксації й цілком перетворився в ембол;

- розповсюджений оклюзивний тромбоз із флотуючою верхівкою, яка становить небезпеку як потенційний ембол;

- імплантаційний флотуючий тромб, який розповсюджується з вісцеральних гілок НПВ при пухлинних ураженнях. Клінічні прояви при цих тромбозах мінімальні, а загроза ТЕЛА надзвичайно висока.

Разом з тим, додаткові методи обстеження не дозволяють із чіткою впевненістю визначити наявність імплантації тромбу в стінку НПВ. Тому інтраопераційний результат залишається основним діагностичним моментом виявлення пухлинної інвазії стінки вени. Підтверджуючими фактами інвазії $\epsilon$ щільна фіксація тромбу до стінки НПВ і неможливість його відділення від стінки. Ретельна ревізія просвіту НПВ дозволяє встановити площу ураження стінки вени і прогнозувати можливі наслідки видалення ушкодженої ділянки. Ми дотримуємося такого алгоритму: якщо після резекції НПВ ії просвіт звузиться до рівня >2/3 просвіту, необхідно застосовувати протезування НПВ.

Усім хворим одним із обов'язкових методів хірургічного лікування було виконання каватомії, яка у 8 (13,8%) пацієнтів закінчилась реконструктивними хірургічними втручаннями на НПВ, причому в 3 із них - протезуванням НПВ (рис. 2,3). У ранньому післяопераційному періоді в 2 (3,4 \%) пацієнтів мала місцегостра ниркова недостатність, яка була ліквідована шляхом медикаментозної терапії протягом 48 год.

Під час гістологічного дослідження стінки НПВ у 79,3 \% випадків було діагностовано різного характеру інвазію пухлини в стінку вени. На рисунках 4,5 представлено гістопрепарати пухлини нирки та пухлинного тромбу із стінкою НПВ. Під час операційного втручання стінка НПВ із ділянкою інвазії була піддана експрес-гістологічному дослідженню, в результаті якого верифіковано інвазію світлоклітинного НКР

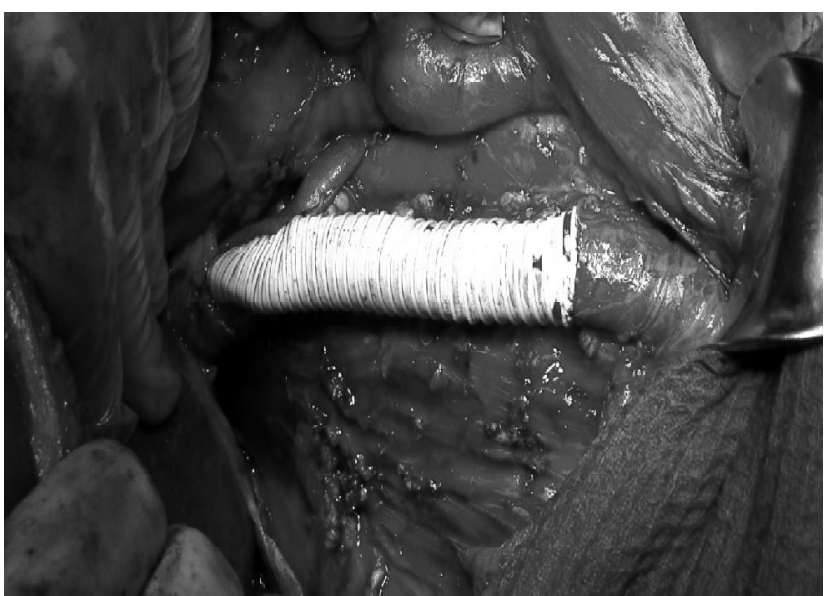

Рис. 2. Інтраопераційне фото. Супра- та інфраренальна ділянка нижньої порожнистої вени відновлена за допомогою протеза Gore Тех. Ліва ниркова вена імплантована в протез.

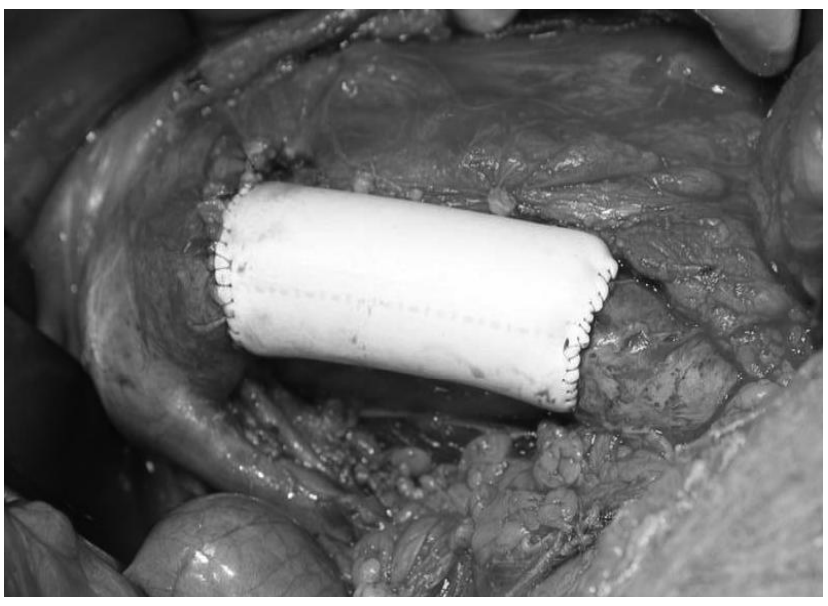

Рис. 3. Інтраопераційне фото. Інфраренальна ділянка нижньої порожнистої вени відновлена за допомогою протеза ПТФЕ.

у стінку НПВ. Враховуючи значну площу ураження НПВ (>2/3 її просвіту), прийнято рішення виконати циркулярну резекцію НПВ вище ниркових вен з наступним протезуванням.

Беззаперечним фактом при лікуванні даної когорти хворих є дотримання чітких критеріїв відбору пацієнтів, що забезпечується ретельним вивченням властивостей як самої пухлини нирки, так і характеру ураження НПВ (ступені поширення пухлинного тромбу, характер інвазії стінки судини).

У літературі [1, 3] описано випадки повного перев'язування НПВ після її циркулярної резекції. Дана ситуація може бути більш сприятливою для правобічного пухлинного тромбозу, коли лівобічні колатералі $€$ більш потужними і значно чисельнішими. У своїй практиці ми не застосовували дану методику, тому що $€$ прихильниками збереження цілісності НПВ шляхом ії протезування. Вважаємо, що особливо актуальним $\epsilon$ дотримання такого напрямку у випадках лівобічного 


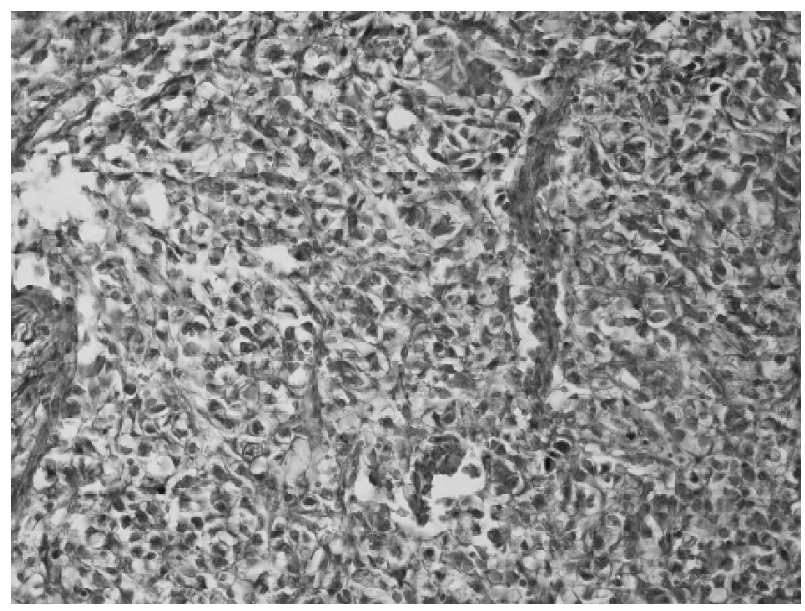

Рис. 4. Хворий А. Гістологічна структура світлоклітинного нирковоклітинного раку. Ступінь злоякісності 4. Забарвлення гематоксиліном та еозином. х200.

пухлинного тромбозу. На нашу думку, протезування НПВ забезпечує фізіологічність відтоку крові без зайвого навантаження на колатералі, які можуть не забезпечити рівноцінний відтік крові.

У жодному з випадків ми не мали епізодів інтраопераційного тромбозу НПВ, ТЕЛА чи летальності. Даний факт вказує на те, що розширені хірургічні втручання на нирці та НПВ при місцевопоширеному НКР можуть застосовуватись у клініках, які мають досвід виконання реконструктивних операцій на судинах.

Висновки. При імплантації нирковоклітинного раку чи пухлинного тромбу в стінку нижньої порожнистої вени необхідно застосовувати ї̈ резекцію.

\section{СПИСОК ЛІТЕРАТУРИ}

1. Давыдов М. И. Хирургическое лечение больных раком почки с опухолевым тромбозом почечной и нижней полой вены / М. И. Давыдов, В. Б. Матвеев // Онкоурология. - 2005. - № 2. - С. 8-15.

2. Оперативные вмешательства на сосудах в онкологической практике / А. М. Гранов, Д. Н. Майстренко, В. Н. Полысалов [и др.] // Медицинский академический журнал. - 2011. - Т. 11, № 1. - С. 70-74.

3. Переверзев А. С. Хирургия опухолей почки и верхних мочевых путей / Переверзев А. С. - X. : Lora medpharm, 1997. - 394 с. 4. Радикальна нефректомія та тромбектомія у хворих на нирково-клітинний рак, ускладнений пухлинним тромбозом ниркової і нижньої порожнистої вен / В. І. Русин, В. В. Корсак, А. В. Русин, С. О. Бойко // Клінічна хірургія. - 2013. - № 1. - С. 21-26.

5. Рак в Україні, 2010-2011: захворюваність, смертність, показники діяльності онкологічної служби. ЗН нирки [Електронний ресурс] // Бюлетень Національного канцер-реєстру. - 2012. - № 13. - Режим доступу до бюлетеня : http://www.ucr. gs.com.ua/dovidb0/PDF/0_20_poch.pdf.

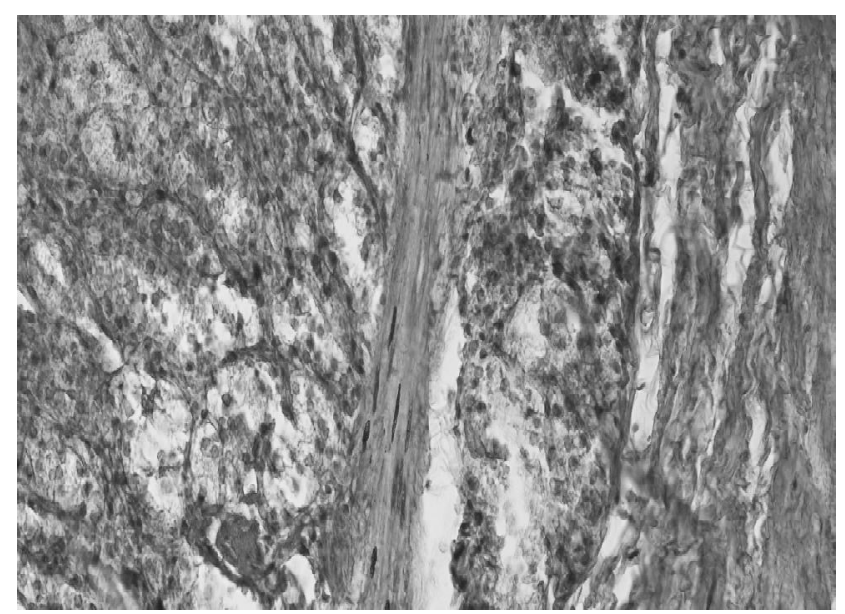

Рис. 5. Той же хворий. Гістологічна структура пухлинного тромбу - світлоклітинний нирковоклітинний рак. Ступінь злоякісності 3-4. Імплантація тромбу в стінку нижньої порожнистої вени. Забарвлення гематоксиліном та еозином. $\mathbf{x 2 0 0 .}$

При звуженні просвіту нижньої порожнистої вени до рівня >2/3 просвіту, після її резекції, необхідно застосовувати протезування нижньої порожнистої вени.

Перспективи подальших досліджень. Перспективним $є$ детальніше гістологічне вивчення видалених макропрепаратів нирки та нижньої порожнистої вени (з обов'язковим експрес-дослідженням на предмет імплантації тромбу в стінку вени) з метою розробки та впровадження більш чітких критеріїв для iї протезування при хірургічному лікуванні нирковоклітинного раку з внутрішньовенозним розповсюдженням та імплантацією тромбу в стінку нижньої порожнистої вени.

6. Флебология : руководство для врачей / [Савельев В. С., Гологорский В. А., Кириенко А. И. и др.] ; под ред. В. С. Савельева. - М. : Медицина, 2001. - 664 с.

7. Antithrombotic therapy for venous thromboembolic disease / C. Kearon, S. R. Kahn, G. Agnelli [et al.] // American College of Chest Physicians Evidence-Based Clinical Practice Guidelines ( $8^{\text {th }}$ Ed) Chest. - 2008. - Vol. 133. - P. 454-545.

8. Blute M. L. The Mayo Clinic experience with surgical management, complications and outcome for patients with renal cell carcinoma and venous tumour thrombus / M. L. Blute, D. C. Leibovich, C. M. Lohse // BJU International. - 2004. - Vol. 94, № 1. - P. 33-41.

9. Catheter-directed thrombolysis vs. anticoagulation alone in deep vein thrombosis: results of an open, randomized trial reporting on short-term patency / T. Enden, N. E. Klow, L. Sandvik [et al.] // J. Thromb. Haemost. - 2009. - Vol. 7. - P. 1268-1275.

10. Quantity of clot lysed after catheter-directed thrombolysis for iliofemoral deep venous thrombosis correlates with postthrombotic morbidity / N. K. Grewal, J. T. Martinez, L. Andrews, A. J. Comerota // J. Vasc. Surg. - 2010. - Vol. 51. - P. 1209-1214. 